\title{
Business Optimization of Shrimp Farming in Indonesia (The Case of Bumi Dipasena Lampung)
}

\author{
M Yusuf S Barusman \\ Faculty of Economy, University of Bandar Lampung Jl. Zainal Abidin Pagar Alam No.26, Labuhan Ratu, \\ Kedaton, 35142, Bandar Lampung, Indonesia \\ Appin Purisky Redaputri* \\ Faculty of Economy, University of Bandar Lampung Jl. Zainal Abidin Pagar Alam No.26, Labuhan Ratu, \\ Kedaton, 35142, Bandar Lampung, Indonesia
}

\begin{abstract}
This study aims to determine the relationship between the level of output produced with the inputs used in conducting shrimp farming on Bumi Dipasena with samples of input and output of shrimp farming in Block 7 Foxtrot, Bumi Dipasena Jaya in 2017. The methodology in this study uses regression Cobb-Douglas production function. The results of this study are that the condition of shrimp farming on Bumi Dipasena block 7 Foxtrot for the 2017 period when viewed from the results is in a decreasing return to scale condition so that the addition of inputs for fries, medicinal feed and fuel is optimal and even unable to increase production output again.
\end{abstract}

Keywords: Business optimization, Cobb douglas, Production function.

DOI: $10.7176 / J R D M / 58-05$

Publication date: August $31^{\text {st }} 2019$

\section{Introduction}

Bumi Dipasena consists of 8 villages which have a total land area of 16,250 HA, divided into independent farming land (ex plasma) type of SHM: 6,800 ha (3,613 ha cultivation area, 3,187 ha supporting infrastructure area) and land ex CPP group (ex core) type HGU covering 9,450 Ha. The total number of ponds which is as many as 17,139 plots consists of productive ponds as many as 14,609 plots and less productive ponds (utilized by the people of these ponds. It is a failure of the CPP group reservoir system) as many as 3070 plots. There are inlet and outlet waterways along 1,300 KM. ${ }^{1}$

At present some of the farmers in Bumi Dipasena manage their ponds, in collaboration with BUMDes with the Sub-Block Business Entity (BUSB) in each block which helps coordinate shrimp farming activities. One of the pioneers that has the most farmers applying this pattern of cooperation is Bumi Dipasena Jaya Village. But the problem is that in 4 periods for one year, the shrimp harvest is very diverse for each harvest period and for each farmer who does the cultivation. The harvest results are influenced by various input factors in the shrimp cultivation process, such as the number of fries distributed, feed, medicine, fuel for the pond producing oxygen, even weather or season conditions that affect the condition of pond water.

The following is an example of the production of shrimp ponds on Bumi Dipasena Jaya in 2017:

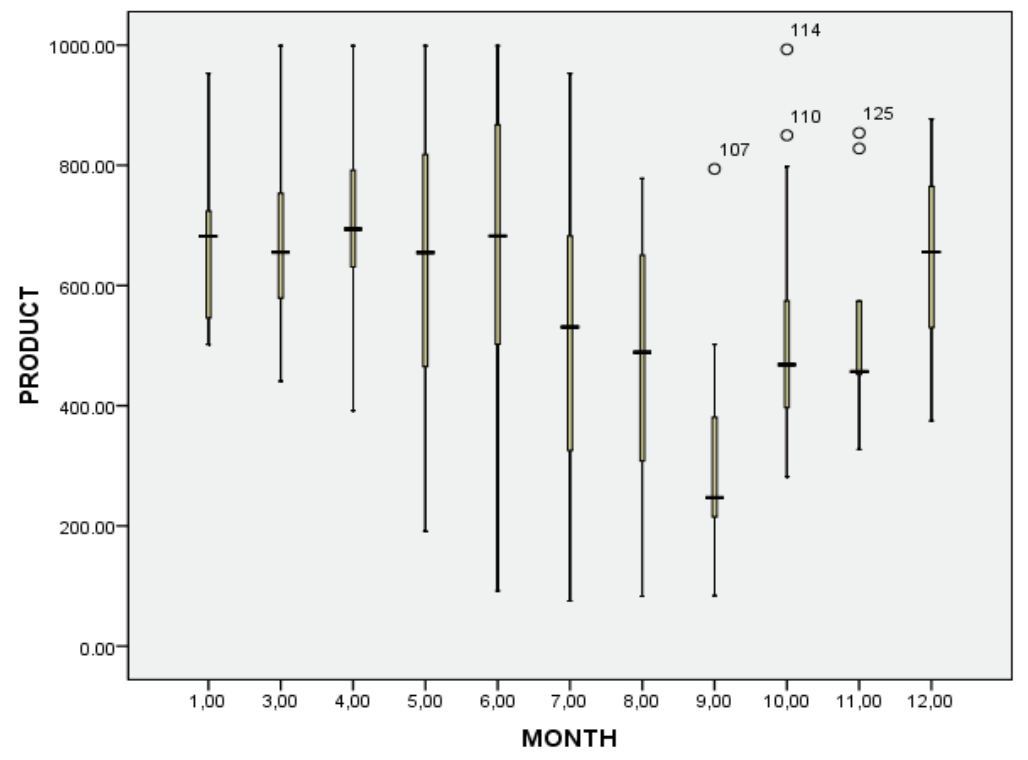

Figure 1 - Mapping of Shrimp Production Results with Boxplots 
Based on the data on shrimp production distribution per month above, it can be seen that in certain months production is below the average, ie from July to November. Even in June and July, every farmer in each period has a wide range of shrimp production. There are farmers who get very high shrimp harvests and some are very low in number. Based on these data, it is necessary to know the relationship between the levels of output produced with the inputs used.

\section{Literature Review}

\subsection{Production Theory}

Production theory is a theory that explains the principles used by business companies to decide how much of each commodity they sell ("output" or "product") to be produced, and how much of each type of labor, raw material, capital goods fixed, etc., which they will use ("input" or "production factors") ( Dorfman , 2018) 2 .

Production is the process of combining various material inputs and immaterial inputs (plans, knowledge) to make something for consumption. This is the act of creating output, goods or services that have value and can contribute to individual use (Kotler, 2006) ${ }^{3}$.

The most important forms of production are:

- market production

- public production

- household production

Production stakeholders are people, groups or organizations with an interest in the company that produces. Economic prosperity comes from efficient production and is distributed through interaction between company stakeholders. The company's stakeholders are economic actors who have economic interests in the company. Based on their common interests, stakeholders can be classified into three groups to differentiate mutual interests and relationships. The three groups are as follows:

1. Customer

Corporate customers are usually consumers, producers or producers of other markets in the public sector. Each has its own production function.

2. Supplier

Company suppliers are usually producers of materials, energy, capital and services. They all have their own production functions.

3. Community producer

Revenue is generated for those who participate in production, namely, the workforce, the community and the owner. These stakeholders here are referred to as the producer community or, in a shorter form, as producers.

\subsection{Production Factors}

In economics, factors of production, resources, or inputs are what are used in the production process to produce output or finished goods and services. The amount used from various inputs determines the quantity of output in accordance with the relationship called the production function.

There are two types of factors: primary and secondary. The main factors mentioned earlier are land, labor (ability to work), and capital goods. Materials and energy are considered secondary factors in classical economics because they are obtained from land, labor and capital. The main factors facilitate production but do not become part of the product (such as with raw materials) or become significantly changed by the production process (such as with fuels used for electric machines). Land does not only cover production sites but also natural resources above or below the ground. Recent use has distinguished human capital (stock of knowledge in the workforce) from labor (Samuelson et al, 2004) ${ }^{4}$. Entrepreneurship is also sometimes considered a factor of production $\left(\mathrm{O}^{\prime}\right.$ Sullivan et al, 2003) ${ }^{5}$. Sometimes the state of technology as a whole is described as a factor of production (Parkin et al, 1999) ${ }^{6}$. The number and definition of factors vary, depending on theoretical goals, empirical emphasis, or school of economics (Friedman, 2007) 7 .

\subsubsection{Total Product}

Total product is the total amount produced over a certain period of time. The total product will change according to the least number of variables used (Lipsey et al, 2001) ${ }^{8}$. The production curve or Total Physical Production Function (TPP) is a curve that shows the relationship of total production with one variable input while the other inputs are considered fixed. The notation for writing the production curve is as follows: TPP $=f(X)(3) 23$ where: $\mathrm{TPP}=$ total output $\mathrm{X}=$ the number of input variables used. If only one type of variable input used in this production case is labor (L), it can be written as follows:

$\mathrm{Q}=\mathrm{f}(\mathrm{L})(4)$

where: $\mathrm{Q}=$ level of output $\mathrm{L}=$ number of labor used.

2.2.2 Average Production

Average production is the total production divided by the number of production factors used to produce the production. So, average production is a comparison of output from the production factor (output-input ratio) for 
each level of output and the factors of production concerned.

$\mathrm{AP}=\mathrm{Q} / \mathrm{L}$

2.2.3 Marginal Productivity

Marginal Productivity or Marginal Physical Product (MPP) is an additional quantity of output produced by adding one unit of input, by assuming constant all other inputs.

$\mathrm{MPP}_{\mathrm{L}}=\frac{\text { Difference in Output }}{\text { Difference in Input }}=\frac{a ? ? F(Q)}{a ? ? L}=\frac{a ? ? Q}{a ? ? L}$

\subsubsection{Relationships Between TPP, APP, MPP and Ep}

Addition to MPP as described above will be more useful when linked to the average product (APP) and total product (TPP). By linking MPP, APP and TPP, the relationship between input and output will be more informative. This means in a way such as production elasticity and whether the production process that is running in a state of low production elasticity or vice versa will be known at once. To explain this, you can use picture 2.4. Based on the picture below we can see that for the first stage there is an additional input that causes additional output to increase (increase rate) then decreases (decreasing negative) to the negative MPP. Based on the picture presented below, various relationships between TPP and MPP can be drawn as well as APP and MPP. Furthermore, from the picture what can be identified from MPP are:

a. MPP continues to rise in circumstances where TPP also rises (stage I)

b. MPP continues to decline in circumstances where TPP is rising (stage II)

c. MPP continues to decline to negative numbers along with TPP which also decreases (stage III)

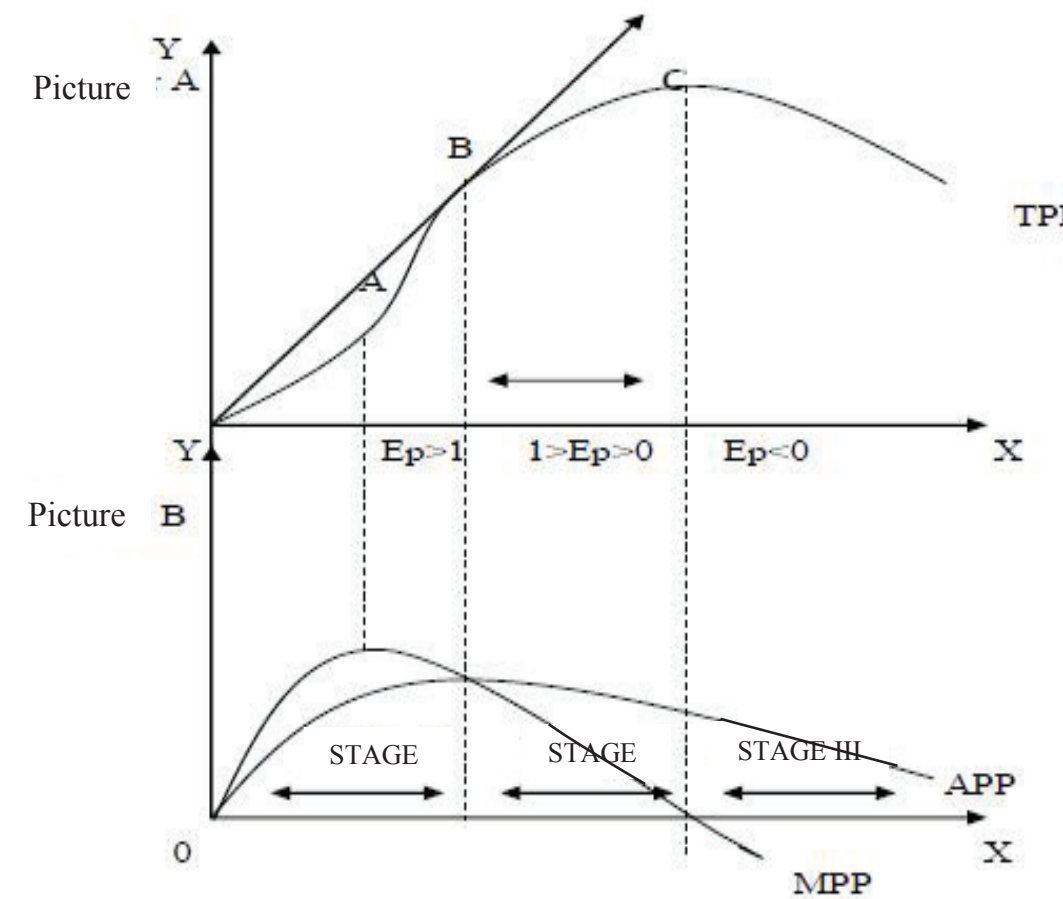

Figure 2 - Production Curve

With information like that, it is found that there are events of stages I, II and III, regions I, II and III are areas that show different elasticities of production.

\subsection{Cobb Douglas}

In economics and econometrics, the Cobb-Douglas production function is a special functional form of the production function, which is widely used to represent the technological relationship between the number of two or more inputs (especially physical capital and labor) and the amount of output that can be produced by that input. The Cobb-Douglas form was developed and tested against statistical evidence by Charles Cobb and Paul Douglas during 1927-1947 (Douglas, 1928) ${ }^{9}$

This production function was first introduced by Cobb, C.W. and Douglas, P.H. in 1928. The Cobb-Douglas production function can be mathematically written in the equation:

$\mathrm{Q}=\mathrm{AK} \alpha \mathrm{L} \beta$ (1)

Information:

Q: total output (production)

$\mathrm{K}$ : capital input

L: labor input 
A: technology efficiency / coefficient parameters

$\alpha$ : elasticity of capital input

$\beta$ : elasticity of labor input

The Cobb-Douglas production function can be obtained by making equation (1) becomes linear, so that it becomes: $\mathrm{LnQ}=\mathrm{LnA}+\alpha \mathrm{LnK}+\beta \mathrm{LnL}+\mathrm{e}(2)$

If the Cobb-Douglas production function as in equation (1) above, the respective marginal physical product for capital and labor input is:

$$
\begin{aligned}
& \frac{d Q}{d K}=M P_{K}=A \cdot \alpha K^{\alpha-1} L^{\beta}=\frac{A \alpha K^{a} L^{\beta}}{K}=\alpha \frac{Q}{K}(3) \\
& \frac{d Q}{d L}=M P_{L}=A \cdot \beta K^{\alpha-1} L^{\beta-1}=\frac{A \beta K^{a} L^{\beta}}{L}=\alpha \frac{Q}{L}(4)
\end{aligned}
$$

If the value of each MP above is associated with elasticity, the features of the Cobb - Douglas production function will be obtained. The elasticity of each input of both capital and labor is:

$$
\begin{aligned}
& \text { Elasticity } \mathrm{K}=\alpha \frac{Q}{K} \cdot \frac{K}{Q}=\alpha(5) \\
& \text { Elasticity } \mathrm{L}=\beta \frac{Q}{L} \cdot \frac{L}{Q}=\beta(6)
\end{aligned}
$$

This elasticity value is very important to explain which input is the most elastic compared to other inputs. In addition, by knowing the elasticity value of each production factor, we can find out whether the production is capital intensive or labor intensive. If $\alpha>\beta$, the nature of production is capital intensive, and if $\alpha<\beta$, the nature of production is labor intensive.

After knowing the elasticity value of each production factor, the sum of the substitution elasticities illustrates the return to scale. If the Cobb - Douglas production function is in equation (2), then the business scale is:

if $\alpha+\beta=1$, constant return to scale applies.

if $\alpha+\beta>1$, increasing return to scale applies.

if $\alpha+\beta<1$, decreasing return to scale applies.

\section{Methodology}

\subsection{Data and Data Sources}

This study uses a case study method. The data used are primary data on input use in the form of seed, feed, medicine and fuel, from ponds in Bumi Dipasena Jaya Village BUSB 7 Foxtrot in 2017. Primary data was obtained through data collection of 53 respondents of shrimp farmers.

\subsection{Data Analysis Models}

The data analysis model is intended to answer questions in the formulation of the problem. In this study the data analysis model used is the Cobb-Douglas production function regression analysis.

Data analysis uses Cobb-Douglas production function regression to see the effect of each input on production results with the following equation:

$\operatorname{LnY}=\operatorname{Ln} A+\alpha 1 \operatorname{Ln} x 1+\alpha 2 \operatorname{Ln} \times 2+\alpha 3 \operatorname{Ln} \times 3+\alpha 4 \operatorname{Ln} \times 4+\alpha 5 \operatorname{Ln} \times 5+\alpha 6 \operatorname{Ln} \times 6+\alpha 7 \operatorname{Ln} \times 7+\mathrm{e}$

Information:

Y : Shrimp production $(\mathrm{kg})$

A : Constant

$\mathrm{x} 1$ : Seed

$\mathrm{x} 2$ : Feed ( S1-01) Sack

$\mathrm{x} 3$ : Feed ( S1-02) Sack

$\mathrm{x} 4$ : Feed ( S1-2P) Sack

x5: Kaptan (Sack)

x6: Saponin (Sack)

x7: Fuel (Solar) Liter

$\alpha 1, \alpha 2, \alpha 3, \alpha 4, \alpha 5, \alpha 6, \alpha 7$ : independent variable coefficient. 


\subsection{Uji Statistik}

\subsubsection{Koefisien Determinasi (R2)}

The coefficient of determination is a concise measure that tells us how well a sample regression line matches the data. R2 is used to see how much the independent variable changes in explaining changes in the dependent variable. The higher the coefficient of determination, the better the ability of independent variables in explaining the behavior of the dependent variable (Gujarati and Porter, 2009) ${ }^{10}$.

\subsubsection{F-Test}

The F-test is used to see overall whether independent variables are statistically significant in influencing the dependent variable. The criteria for this testing are done by comparing F - count and certain F - tables. Ho is accepted if: $F$ - count $\leq F$ - table, meaning there is no effect of the overall independent variable and $F$ - count $\geq F$ table, meaning that there is no overall independent variable effect.

\subsubsection{T-Test}

The t-test is used to test or calculate the effect of each independent variable individually on the dependent variable. The hypothesis to reject or accept the hypothesis is explained as follows:

Ho: $\alpha 1=0$, meaning: (there is no influence between the independent variables on the dependent variable).

Ha: $\alpha 1 \neq 0$, meaning: (there is an iinfluence between the independent variables on the dependent variable).

The hypothesis in the t-test is based on the hypothesis testing approach of the significance testing method developed by R.A Fisher and Newman-Pearson (Gujarati dan Porter,2009) ${ }^{10}$. The significance testing procedure is used to find out whether the testing criteria are stated to meet the null hypothesis or not.

\section{Results and Discussion}

4.1 Cobb Douglas Calculation Results with SPSS

4.1.1 Normality Test

Normal P-P Plot of Regression Standardized Residual

Dependent Variable: Produksi

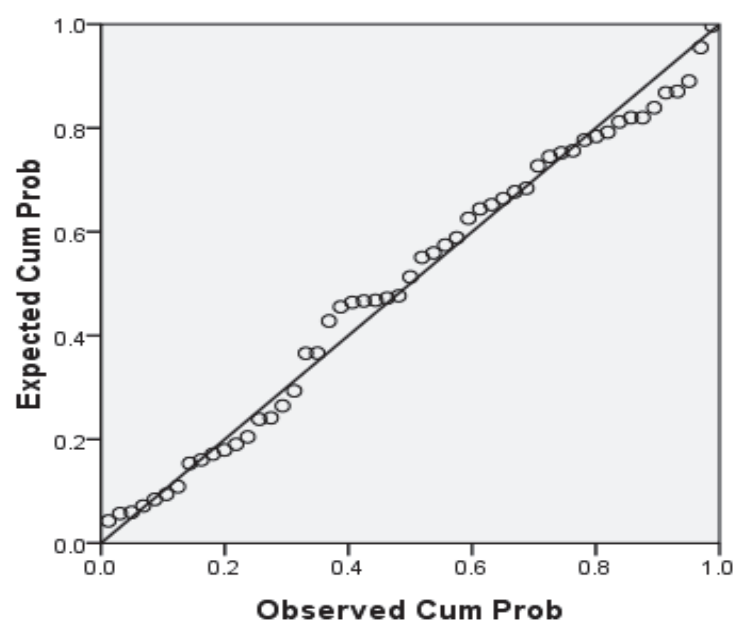

Figure 3 - P-P Plot of Shrimp Ponds in Bumi Dipasena

The assumption of normality is tested by looking at the shape of the normal P-P plot curve. If the P-P plot follows a normal (straight) line then the normal assumption can be accepted. From the results of data processing it can be seen that the P-P curve of the plot has followed the normal line so that the assumption of normality is met.

4.2.2 Hypothesis Testing

Hypothesis testing is used to answer the first problem formulation.

\subsubsection{F Test}

a. Formulating Hypotheses

Ho: $\beta 1, \beta 2, \beta 3=0$, then seed, feed SI-01, SI-02, SI-2P, kaptan, saponin and fuel simultaneously have no effect on shrimp production.

Ha: At least one of $\beta \mathrm{i} \neq 0$, then seed, feed, SI-01, SI-02, SI-2P, kaptan, saponin and fuel simultaneously affect shrimp production.

b. Determining the Level of Significance $(\alpha)$

Determine the level of significance of $5 \%$ with the level of confidence of $95 \%$. 
c. Determining the Testing Criteria

Ho is rejected $\mathrm{F}$ count $>$ Ftable

Ho is accepted if $\mathrm{F}$ count $\leq$ Ftable

Table 3- Result of F Test

ANOVA

\begin{tabular}{|l|c|c|c|c|c|}
\hline \multicolumn{1}{|c|}{ Model } & Sum of Squares & df & Mean Square & F & Sig. \\
\hline Regression & 1.690 & 7 & .241 & 3.101 & $.009^{\mathrm{a}}$ \\
Residual & 3.504 & 45 & .078 & & \\
Total & 5.193 & 52 & & & \\
\hline
\end{tabular}

a. Predictors: (Constant), Fuel, Drug 1, Seed, Drug 2, Feed 1, Feed 3, Feed 2

b. Dependent Variable: Production

Based on table 3, the calculated $\mathrm{F}$ value is 3.101 greater than $\mathrm{F}$ table of 2.19. From the table sum of squares regression of 1,690 is obtained from $\Sigma\left(\mathrm{Y}_{-}{ }_{-}\right)^{2}$, that is the difference between the original $\mathrm{Y}$ and the average $\mathrm{Y}$ squared and sum of square residuals of 3,504 obtained from dari ( $\left.\mathrm{Y}^{\prime}-\mathrm{Y}\right)^{2}$, that is the difference between $\mathrm{Y}$ estimates with original $Y$. The mean of square obtained from sum of square is divided by df.

The calculated $F$ value is 3.101 greater than $F$ table of 2.19 . When viewed from the probability level, the calculation shows that the probability value is 0.09 smaller than the significant level of $0.05(\alpha)$, so it can be concluded that Ho is rejected, which means that seed, feed SI-01, SI-02, SI -2P, kaptan, saponin and fuel simultaneously affect shrimp production.

4.2.3.2 T-Test

The t-test aims to determine the partial effect of independent variables consisting of seed, feed SI-01, SI-02, SI2P, kaptan, saponins and fuel to the company's output in the form of shrimp production in Bumi Dipasena shrimp ponds. In the unstandardized coefficient column, B shows the regression parameter coefficients generated using an ordinary variable (not standardized) because it uses units or the original scale of the variables used.

In the standardized coefficient column, beta shows the standardized variables regression parameter (variables whose data has been standardized with the standard deviation of each variable).

Table 4- Result of T-Test

Coefficients ${ }^{\mathrm{a}}$

\begin{tabular}{|c|c|c|c|c|c|}
\hline \multirow{2}{*}{ Model } & \multicolumn{2}{|l|}{ Unstandardized Coefficients } & Standardized Coefficients & \multirow{2}{*}{ Sig. } \\
\cline { 2 - 5 } & $\mathrm{B}$ & Std. Error & Beta & $\mathrm{t}$ & Sig. \\
\hline 1 (Constant) & 2.835 & 1.388 & & 2.043 & .047 \\
Seed & .738 & .259 & .401 & .844 & .007 \\
Feed 1 & .007 & .057 & .018 & .129 & .898 \\
Feed 2 & -.019 & .063 & -.046 & -.302 & .764 \\
Feed 3 & .079 & .038 & .299 & 2.090 & .042 \\
Drug 1 & .136 & .146 & .123 & .932 & .356 \\
Drug 2 & -.021 & .097 & -.031 & -.215 & .830 \\
Fuel & -.041 & .109 & -.049 & -.370 & .713 \\
\hline
\end{tabular}

Dependent Variable: Production

a. From the results of the analysis, the $t$-count value for fry is 2,844 . Because the $t$-count value is $2,844>t$-table is 1.67 , the probability value is $0.007<\alpha(0.05)$ so it can be concluded that seeds have a significant effect on the number of shrimp products produced.

b. From the results of the analysis, the t-count value for SI-01 feed was 0.129 . Because the t-count value of 0.129 $<\mathrm{t}$-table is 1.67 , the probability value is $0.898>\alpha(0.05)$ so it can be concluded that the feed (SI-01) does not significantly influence the amount of shrimp production produced.

c. From the results of the analysis, the SI-02 feed t-count value was -0.0302 . Because the t-count value is -0.0302 $<\mathrm{t}$-table of 1.67 , the probability value is $0.764>\alpha(0.05)$ so it can be concluded that feed (SI-02) has no significant effect on the amount of shrimp production produced.

d. From the results of the analysis, the t-count value for SI-2P feed was 2,090. Because the t-count value is 2.090> t-table of 1.67 , the probability value is $0.042<\alpha(0.05)$ so it can be concluded that feed (SI-2P) has a significant effect on the amount of shrimp production produced. 
e. From the results of the analysis, the $\mathrm{t}$-count value for Kaptan is 0.932 . Because the $\mathrm{t}$-count value of $0.932<\mathrm{t}$ table is 1.67 , the probability value is $0.356>\alpha(0.05)$ so it can be concluded that Kaptan has no significant effect on the amount of shrimp production produced.

f. From the results of the analysis, the t-calculated value for Saponin is -0.215 . Because the t-count value is $0.215<\mathrm{t}$-table of 1.67 , the probability value is $0.830>\alpha(0.05)$ so it can be concluded that Saponin has no significant effect on the amount of shrimp production produced.

g. From the results of the analysis obtained the value of t-count for BBM is -0.370 . Because the t-count value of $-0.370<$ t-table is 1.67 , the probability value is $0.713>\alpha(0.05)$ so it can be concluded that fuel does not significantly influence the amount of shrimp production produced.

Based on the results of the T test, seed and one type of feed namely SI-2P turned out to have a significant effect on the amount of shrimp production. The seed is a shrimp seed that is stocked first in the implementation of shrimp cultivation. The quality of seeds and the number of seeds certainly has a significant effect on shrimp production. Then the SI-2P feed type turned out to have a significant effect on shrimp production compared to other types of feed. Like the type of feed SI-01, SI-02, kaptan, saponin and fuel which have no significant effect on the amount of shrimp production. If you re-analyze the fuel in shrimp cultivation, it is used to operate the windmill at night for the production of oxygen in the pond. But based on calculations it turns out that the fuel has no significant effect on shrimp production.

4.2.3.3 Adjusted R Square Test

Table 5- Adjusted R Square Test Results

Model Summary ${ }^{\mathrm{b}}$

\begin{tabular}{|c|c|c|c|c|c|}
\hline Model & $\mathrm{R}$ & $\mathrm{R}$ Square & Adjusted R Square & Std. Error of the Estimate & Durbin-Watson \\
\hline 1 & $.570^{\mathrm{a}}$ & .325 & .220 & .27903 & 1.946 \\
\hline
\end{tabular}

a. Predictors: (Constant), BBM, Obat1, Benur, Obat2, Pakan1, Pakan3, Pakan2

b. Dependent Variable: Produksi

In table 5 , it can be seen that the Adjusted $\mathrm{R}$ square value is 0.220 . It shows that $22 \%$ of shrimp production can be explained by the variable fry (X1), SI-01 (X2), SI-02 (X3), SI-2P (X4), (X5), saponin (X6) and BBM (X7) while the remaining $78 \%$ is explained by other variables. Another variable that might affect the amount of shrimp production is the weather and season which will also affect the pond water conditions. The pond area and the expertise of the farmers themselves can also affect shrimp production. The standard error of estimate shows the predictive level of regression. The smaller the Standard error of estimate value the more precise predictions made in explaining the effect of independent variables on the dependent variable.

\subsection{Multiple Regression Analysis}

After testing the classical assumptions, the F test and $t$ test then to answer the formulation of the second and third problems carried out multiple linear regression analysis. The linear regression model used in testing the hypothesis is formulated as follows:

$\mathrm{Y}=\mathrm{a} X 1 \mathrm{~b}$ X2c X3dX4eX5fX6gX7h

Information:

$\mathrm{Y}=$ output

$\mathrm{a}=$ Constant Value

$\mathrm{X} 1=$ Seed

$\mathrm{X} 2=$ Feed $(\mathrm{SI}-01)$

$\mathrm{X} 3=$ Feed $(\mathrm{SI}-02)$

$\mathrm{X} 4=$ Feed $(\mathrm{SI}-2 \mathrm{P})$

$\mathrm{X} 5=$ Kaptan

$\mathrm{X} 6=$ Saponin

$\mathrm{X} 7=$ Fuel

b,c,d,e,f,g,h = Input elasticity

The function equation above is the original formulation of the Cobb-Douglas production function with three independent variables. After all variables are converted into natural logarithms (Ln), the formulation of the function is transformed into the Ln equation, so the equation becomes:

$\mathrm{Ln} \mathrm{Y}=\mathrm{Ln} \mathrm{a}+\mathrm{b} \ln \mathrm{X} 1+\mathrm{c} \ln \mathrm{X} 2+\mathrm{d} \ln \mathrm{X} 3+\mathrm{e} \ln \mathrm{X} 4+\mathrm{f} \ln \mathrm{X} 5+\mathrm{g} \ln \mathrm{X} 6+\mathrm{h} \ln \mathrm{X} 7$ 
Table 5- Results of Multiple Regression Analysis Coefficients Coefficients $^{\mathrm{a}}$

\begin{tabular}{|c|c|c|c|c|c|}
\hline \multirow{2}{*}{ Model } & \multicolumn{2}{|l|}{ Unstandardized Coefficients } & Standardized Coefficients & \multirow{2}{*}{ Sig. } \\
\cline { 2 - 5 } & $\mathrm{B}$ & Std. Error & Beta & 2.043 & .047 \\
1 (Constant) & 2.835 & 1.388 & & 2.844 & .007 \\
Seed & .738 & .259 & .401 & .129 & .898 \\
Feed 1 & .007 & .057 & .018 & -.302 & .764 \\
Feed 2 & -.019 & .063 & -.046 & 2.090 & .042 \\
Feed 3 & .079 & .038 & .299 & .932 & .356 \\
Drug 1 & .136 & .146 & .123 & -.215 & .830 \\
Drug 2 & -.021 & .097 & -.031 & -.370 & .713 \\
Fuel & -.041 & .109 & -.049 & & \\
\hline
\end{tabular}

a. Dependent Variable: Production

In the table above, multiple regressions analysis that is processed with the help of SPSS 16.0 for windows produce the regression equation as follows:

$\mathrm{Ln} Y=\ln 2,835+0,738 \ln \mathrm{X} 1-0,007 \ln \mathrm{X} 2-0,019 \ln \mathrm{X} 3+0,079 \ln \mathrm{X} 4+0,136 \ln \mathrm{X} 5-0,021 \ln \mathrm{X} 6-0,041 \ln$ $\mathrm{X} 7+2,718$

From the form of Cobb-Douglas production function transformation above, the form is changed back to the original Cobb-Douglas production function, so that the equation becomes:

$\mathrm{Y}=17,030 \mathrm{X} 1^{0,738} \mathrm{X} 2^{-0,007} \mathrm{X} 3^{-0,019} \mathrm{X} 4^{0,079} \mathrm{X} 5^{0,136} \mathrm{X} 6^{-0,021} \mathrm{X} 7^{-0,041}$

From the results of the analysis above the magnitude of the elasticity of each independent variable can be seen from the magnitude of the rank coefficient on each independent variable. Seed elasticity of 0.738 , feed elasticity (SI-01) of -0.007 , feed elasticity (SI-02) of -0.019 , feed elasticity (SI-2P) of 0.079 , kaptan elasticity of 0.136 , saponin elasticity of -0.021 , and fuel elasticity of -0.041 .

These results indicate that the elasticity of each input variable is smaller than one so that the fries variable, feed SI-01, SI-02, SI-2P, kaptan, saponin and fuel are inelastic. If X1 (seed) rises by 1\% then Y (shrimp production) will increase by $0,738 \%$ ceteris paribus, X2 (SI-01) rises by $1 \%$ then Y (shrimp production) will decrease by $0,007 \%$ ceteris paribus, X3 (SI-02) rises by $1 \%$ then Y (shrimp production) will decrease by $0,019 \%$ ceteris paribus, X4 (SI-2P) rises by $1 \%$ then Y (shrimp production) will increase by $0,079 \%$ ceteris paribus, X5 (kaptan) rises by $1 \%$ then $\mathrm{Y}$ (shrimp production) will decrease by $0,136 \%$ ceteris paribus, X6 (saponin) decreases by $1 \%$ then Y (shrimp production) will decrease by $0,021 \%$ ceteris paribus, X7 (fuel) decreases by $1 \%$ then Y (shrimp production) will decrease by $0,041 \%$ ceteris paribus,

The amount of Return to scale can be calculated by summing the rank coefficients of each independent variable $(0.738-0.007-0.019+0,079+0,136-0,021-0,041=0,865)$ which shows that the company is in a decreasing return to scale condition. This means that the addition of production factors will produce additional production output which has a smaller proportion so that the addition of input for fries, medicinal feed and fuel is optimal and even unable to increase production output again. For this reason, it is necessary to make other efforts to increase production output. By paying attention to other input factors such as land, climate, investment capital and shrimp disease. For example, shrimp cultivation in the Mekong Delta in the southernmost part of Vietnam. It was discovered that farmers faced including limited access to mangrove forests, crop failure due to regular occurrence of shrimp disease, high investment costs and volatile markets for shrimp (Thi Phung Ha, 2013) ${ }^{11}$.

In another study on Economic efficiency of small-scale tilapia farms in Guangxi, China (Zongli, et al, 2016) ${ }^{12}$. The decomposition of the economic efficiency showed that allocative efficiency was the primary cause of economic inefficiency. There are positive relationships between economic efficiency and age, culture mode and period through Tobit regression, while experience, family members, and technology support have negative effects on economic efficiency. Lower input levels of feed may help to increase the tilapia farming economic efficiency.

\section{Conclusion}

1. Variables X1 (seed) and X4 feed (SI-2P) significantly influence the variable Y (shrimp production) while the variables X2 (SI-01), X3 (SI-02), X5 (kaptan), X6 (saponin) and X7 (fuel) does not significantly influence the variable Y (shrimp production) in Bumi Dipasena shrimp pond, especially block 7 Foxtrot. Seed and feed type SI-2P are independent variables that have a significant effect on the production process. Without the SI-2P seed and feed, the production process cannot run. Whereas feed type SI-01, SI-02, kaptan, and saponin have no significant effect on production because in the process of vaname shrimp cultivation, there are still many 
types of feed and medicines that can have a significant effect. Whereas for fuel, the one used to operate the water mill is also not significant because the condition of the pond water can be influenced by various things, such as $\mathrm{PH}$ and ammonia.

2. The elasticity of each input variable is smaller than one so that the fries variable, feed SI-01, SI-02, SI-2P, kaptan, saponin and BBM are inelastic. If X1 (seed) rises by $1 \%$ then $\mathrm{Y}$ (shrimp production) will increase by $0,738 \%$ ceteris paribus, X2 (SI-01) increases by $1 \%$ then Y (shrimp production) will decrease by $0,007 \%$ ceteris paribus, X3 (SI-02) increases by 1\% then Y (shrimp production) will decrease by $0,019 \%$ ceteris paribus, X4 (SI-2P) increases by $1 \%$ then Y (shrimp production) will increase by $0,079 \%$ ceteris paribus, X5 (kaptan) increases by $1 \%$ then Y (shrimp production) will decrease by $0,136 \%$ ceteris paribus, X6 (saponin) decreases by $1 \%$ then Y (shrimp production) will decrease by $0,021 \%$ ceteris paribus, X7 (fuel) decreases by $1 \%$ then Y (shrimp production) will decrease by $0,041 \%$ ceteris paribus.

3. Shrimp Farming in Bumi Dipasena block 7 Foxtrot in the 2017 period when viewed from the scale of the results is in a condition of decreasing return to scale. The addition of production factors will result in additional production output with a smaller proportion. In other words, the current condition of Bumi Dipasena has exceeded production optimization and has tended to decrease so that the addition of inputs for seeds, medicinal feed and fuel has been optimally so that it is unable to increase production output again. For this reason, another effort is needed to increase production output such as the implementation of pond expansion. Because optimization of business processes is important part of continual improvement of production processes. Continual improvement it means to improve product, services, processes (Teplicka et al, 2015) ${ }^{13}$.

\section{References}

Anonnimous., 2016, Company Profle. Bumi Dipasena, Rawa Jitu, Tulang Bawang [1]

Dorfman, R., 2018, Theory Of Production (Economics), Encyclopedia Britannica.

https://www.britannica.com/topic/theory-of-production [2]

Friedman, M., 2007, Price Theory, Transaction Publishers, p. 201. ISBN 978-0-202-30969-9.[7]

Cobb, C. W.; Douglas, P. H., 1928, "A Theory of Production" (PDF), American Economic Review. 18 (Supplement): 139-165.[9]

Gujarati, D.N. and Porter, D.C., 2009, Basic Econometrics. 5th Edition, McGraw Hill Inc., New York[10]

"Kotler", P., Armstrong, G., Brown, L., and Adam, S., 2006, Marketing, 7th Ed. Pearson Education Australia/Prentice Hall.[3]

Lipsey, R.G and Carlaw K.I., 2001, What Does Total Factor Productivity Measure?, (available at http://www.csls.ca/ipm/1/lipsey-e.pdf) [8]

O'Sullivan, A and Sheffrin, S.M., 2003, Economics: Principles in Action, Upper Saddle River, New Jersey 07458 : Pearson[5]

Parkin, M., and Esquivel. G., 1999, Macroeconomía (in Spanish) (5th ed.), Mexico: Addison Wesley. p. 160. ISBN 968-444-441-9.[6]

Samuelson, P.A and Nordhaus. W.d., 2004, Economics, 18th ed., "Factors of production", "Capital", Human capital", and "Land" under Glossary of Terms.[4]

Teplická K., Čulková K., Železník O., 2015, Application of Bayess Principle Optimum-Optimization Model For Managerial Decision and Continual Improvement, Polish Journal of Management Studies,12(2), pp 170179.[13]

Tran Thi Phung Ha, Han van Dijk, Roel Bosma \& Le Xuan Sinh., 2013, LIVELIHOOD CAPABILITIES AND PATHWAYS OF SHRIMP FARMERS IN THE MEKONG DELTA, VIETNAM, Aquaculture Economics \& Management, 17:1, 1-30, DOI: 10.1080/13657305.2013.747224. [11]

Zhang Zongli, Zhang Yanan, Li Feifan, Yang Hui, Yuan Yongming \& Yuan Xinhua., 2017, Economic efficiency of small-scale tilapia farms in Guangxi, China, Aquaculture Economics \& Management, 21:2, 283-294, DOI: 10.1080/13657305.2016.1180644. [12] 